\author{
Jelena Kostić* \\ Marina Matić Bošković ${ }^{\star *}$
}

\title{
HOW COVID-19 PANDEMIC INFLUENCES RULE OF LAW BACKSLIDING IN EUROPE
}

The phenomenon of rule of law backsliding raised attention over the last decade after judicial reforms in Hungary and Poland where Governments have sought to reduce judicial independence and jeopardize checks and balances by limiting the power of their respective constitutional courts. The EU has activated political and legal mechanism to address challenges with rule of law in member states, while negotiation processes with accession countries provide more options for influence on judicial reforms.

However, new challenges for rule of law are raised. For the past few months, Europe and the world have been facing with COVID-19 pandemic that put at risk the lives of the people and capability of healthcare systems to provide their services. To prevent the spread of the COVID-19, governments have imposed restrictive measures, while some of them declared state of emergency. The greatest threat for rule of law in Europe is posed by the recent events in Hungary, where unrestricted powers of ruling by decree were given to the government, without any deadline, without any further parliamentary control. Some countries introduced new crimes that could violate human rights. COVID-19 pandemic has posed unprecedented challenges to the functioning of judiciaries. Courts and prosecution services are working with limited capacities to ensure social distancing. Some countries, like Serbia, introduced ICT tools to organize hearings, which raised the question of protecting the rights of defendants. Despite the obvious need for introducing extraordinary measures during pandemic, these measures should be proportionate and time limited.

The paper offers an assessment of the recently introduced changes, restrictions and fast-track procedures that jeopardize separation of powers and rule of law in EU member states and candidate countries. Authors emphasized the need to protect rule of law and independence and impartiality of the judiciary in order to prevent further erosion of the rule of law, separation of powers and position of the judiciary in the member states. The

\footnotetext{
* Jelena Kostić, PhD, Research Fellow, Institute for Comparative Law, Belgrade. E-mail address: j.kostic@iup.rs.

${ }^{*}$ Marina Matić Bošković, PhD, Research Fellow, Institute of Criminological and Sociological Research, Belgrade. E-mail address: m.m.boskovic@roldevelopmentlab.com.
} 
role of independent courts is even more essential during the emergency period to protect citizens' fundamental rights and freedoms against any kind of violation or abuse.

Keywords: rule of law backsliding, separation of powers, independence of judiciary, emergency measures.

\section{WHY THE RULE OF LAW MATTERS}

The rule of law is at the core of the EU system. Although the origins of the notion to the rule of law can be traced to Ancient Greece, the European Commission provided its own understanding of the rule of law. Under the rule of law, all public authorities always act within the constraints set out by law, in accordance with the values of democracy and fundamental rights, and under the control of independent and impartial courts. ${ }^{104}$ The rule of law requires the respect of legality, equality of citizens, legal certainty, independence of the judiciary, accountability of decision-makers and the protection of human rights. ${ }^{105}$

The rule of law is incorporated in the EU founding treaties and case law of EU Court of Justice. In a judgment Les Verts, the Court of Justice of the European Union for the first time referred to what was then known as the European Community as "based on the rule of law" (von Danwitz, 2012: 1314). ${ }^{106}$ This judicial reference was followed by the treaty amendments that reinforced the significance of the rule of law. The 1997 Amsterdam Treaty inserted a new provision into the EU Treaty which provided that the Union is founded on the rule of law, ${ }^{107}$ which is later replicated in the 2007 Lisbon Treaty.

According to Article 2 of the Treaty of European Union, the Union is founded on the values of respect for human dignity, freedom, democracy, equality, the rule of law and respect for human rights, including the rights of persons belonging to minorities. The abovementioned values are common to the member states in a society in which pluralism, non-discrimination, tolerance, justice, solidarity and equality between women and men prevail.

The European Commission, together with all other EU institutions, is responsible under the Treaties for guaranteeing the respect of the rule of law as a fundamental value of the Union and making sure that EU law, values and principles are respected. ${ }^{108}$ The rule of law means that all members of a society - governments and parliaments included - are equally subject to the law, under the control of independent courts, irrespective of political majorities.

\footnotetext{
${ }^{104}$ Communication from the Commission to the European Parliament, the Council, the European Economic and Social Committee and the Committee of the Regions, 2020 Rule of Law Report, The rule of law situation in the European Union, $\{\operatorname{SWD}(2020) 300-326\}, \operatorname{COM}(2020) 580$ final, p. 1.

${ }^{105}$ See, e.g., Case C-503/15 Ramón Margarit Panicello v Pilar Hernández Martínez, EU:C:2017:126, para. 37-38. ${ }^{106}$ Case 294/83 Les Verts v Parliament [1986] ECR 1339, para. 23.

${ }^{107}$ Ex-Article 6(1) of the Treaty of EU.

${ }^{108}$ Editorial Comments, (2016) The Rule of Law in the Union, the Rule of Union Law and the Rule of Law by the Union: Three interrelated problems, Common Market Law Review (2016), Vol 53, p. 599.
} 
The rule of law principle is further included in the Charter of Fundamental Rights of the EU. According to article 47 paragraph 2 the Charter of Fundamental Rights of the EU everyone is entitled to a fair and public hearing within a reasonable time by an independent and impartial tribunal previously established by law.

In the EU founding treaties, the rule of law is also used as a benchmark to assess the action of candidate countries and compliance with the rule of law is set as a condition for EU membership (Halmai, 2018: 172). The Amsterdam Treaty stressed the importance of the political criteria and inserted a provision of article 49 TEU, which provides that "any European State which respects the values referred to in Article 2 and is committed to promoting them may apply to become a member of the Union". The rule of law chapters, 23 and 24 of the acquis, are at the heart of the European accession process. European Commission expectations of candidate countries are compliance with EU principles relating to the Rule of Law, Judiciary, Fundamental Rights and Anti-Corruption. Areas of focus of Chapter 23 of accession negotiations focus on improving judicial independence, both conceptually and functionally, and strengthening impartiality, accountability, professionalism and efficiency of the judiciary. The oversight of the rule of law should continue after accession of the country to ensure continuation of consistency with the rule of law values (Closa, 2016:19).

Independence of the judiciary as one of the elements of the rule of law is a value separately treated in the EU founding treaties. In accordance with Article 19(1) Treaty of $\mathrm{EU}$, the member states are obliged to ensure that courts and tribunals within the meaning of the EU law meet the requirement of effective legal protection within the denotation of the Charter of Fundamental Rights of the EU. Courts and tribunals can provide such protection only if sustaining their independence (Matić Bošković, 2020: 333).

According to the Venice Commission Opinion on the protection of human rights in emergency situations, the rule of law must prevail. ${ }^{109}$ It is a fundamental principle of the rule of law that state actions must be in accordance with the law, including emergency decrees of the executive. ${ }^{110}$ In many countries, constitutions provide for a special legal regime, increasing powers of the executive in case of war or a major natural disaster or another calamity. Additionally, the state of emergency should be of limited duration and scope. However, checks on the execute actions during the state of emergency must be ensured through parliament and the judiciary. ${ }^{111}$ The role of the judiciary becomes even more important during the time of emergency, since the judiciary serves as an essential check on the other branches of the state and ensures that any laws and measures adopted to address the crisis comply with the rule of law, human rights and, where applicable, international humanitarian law. ${ }^{112}$

\footnotetext{
${ }^{109}$ CDL-AD(2006)015), para. 13.

${ }^{110}$ Venice Commission Rule of Law Checklist (CDL-AD(2016)007), paras. 44 and 45.

${ }^{111}$ PACE Recommendation 1713 (2005), Democratic oversight of the security sector in member states, p. 38.

112 Legal Commentary to the ICJ Geneva DeclarationUpholding the Rule of Law and the Role of Judges and Lawyers in Times of Crisis, International Commission of Jurists, 2011.
} 


\section{BACKSLIDING OF THE RULE OF LAW IN THE EU}

Shortcomings in the rule of law in one member state impact other member states and the EU as a whole and challenge its legal, political and economic basis. Should an EU member state be suspected of breaching the rule of law, a number of procedures are available to verify this and remedy the situation (Konstadinides, 2017: 38).

Since 2015, the Polish authorities have enacted a series of judicial reforms including the creation of new disciplinary procedures and a supervisory body that have dramatically increased political oversight of the judiciary (Pech, Scheppele, 2017:3). As early as 2016, the European Commission triggered its mechanism under the EU Framework to strengthen the rule of law and to prevent further adverse developments regarding it in Poland by adopting $1^{\text {st }}$ Rule of law recommendation 2016/1374 (Bogdany et al, 2018: 983). ${ }^{113}$ The EU Commission concluded that legislative reforms in the area of court organizations would limit the independence of ordinary courts (Niklewicz, 2017: 284). In addition, judgement of the EU Court of Justice in Case C/216 PPU regarding the decision of the Irish high judge to refuse to extradite a suspected drugs trafficker to Poland due to concerns about the integrity of the Polish justice system, re-confirms the relevance of the rule of law for the EU. The safeguarding of judicial independence in Poland was one of the country-specific recommendations addressed in the context of the 2020 European Semester. ${ }^{114}$

The same mechanism was triggered against Hungary in 2017 for concerns about the functioning of the country's institutions, including problems with the electoral systems, independence of the judiciary and the respect for citizens' rights and freedoms (Müller, 2015: 151). ${ }^{15}$ One of the problems in Hungary was the fact that the competences of the Hungarian Constitutional Court were limited as a result of the constitutional reform, even

${ }^{113}$ Commission Recommendation (EU) 2018/103 of 20 December 2017 Regarding the Rule of Law in Poland Complementary to Recommendations (EU) 2016/1374, (EU) 2017/146 and (EU) 2017/1520, 2017 O.J.(L 17/50),https://eur-lex.europa.eu/legal-content/EN/TXT/PDF/?uri=CELEX:32018H0103\&from=EN.

${ }^{114}$ Council Recommendation of 20 July 2020 on the 2020 National Reform Programme of Poland and delivering a Council opinion on the 2020 Convergence Programme of Poland, p. 15 (OJ C 282/21); see also European Commission, Country Report Poland 2020, SWD(2020) 520 final, p. 6 and 36.

${ }^{115}$ European Parliament resolution of 12 September 2018 on a proposal calling on the Council to determine, pursuant to Article 7(1) of the Treaty on European Union, the existence of a clear risk of a serious breach by Hungary of the values on which the Union is founded, 2017/2131(INL). According to article 7(1) of the Treaty on European Union in a reasoned proposal by one third of the Member States, by the European Parliament or by the European Commission, the Council, acting by a majority of four fifths of its members after obtaining the consent of the European Parliament, may determine that there is a clear risk of a serious breach by a Member State of the values referred to in Article 2. Before making such a determination, the Council shall hear the Member State in question and may address recommendations to it, acting in accordance with the same procedure. The Council shall regularly verify that the grounds on which such a determination was made continue to apply. According to Article 7(2) of TEU the European Union Council acting by unanimity on a proposal by one third of the Member States or by the Commission and after obtaining the consent of the European Parliament, may determine the existence of a serious and persistent breach by a Member States of the values referred to in Article 2., after inviting the Member State in question to submit its observations. In situations when a determination has been made, the Council, acting by a qualified majority, may decide to suspend certain of the rights deriving from the application of the Treaties to the Member State in question, including the voting rights of the representative of the government of that Member State in the Council. 
with regard to budgetary matters, the abolition of the action popularis and other important issues. The Venice Commission expressed concerns about the mentioned limitations and the procedure for the appointment of judges. The Venice Commission made recommendations to the Hungarian authorities to ensure the necessary checks and balances in its Opinion on Act CLI of 2011 on the Constitutional Court of Hungary adopted on 19 June 2012 and in its Opinion on the Fourth Amendment to the Fundamental Law on Hungary adopted on 17 June 2013. During 2018,the UN Human Rights Committee expressed concerns that the current constitutional complaint procedure affords more limited access to the Constitutional Court, does not provide for a time limit for the exercise of constitutional review and does not have a suspensive effect on challenged legislation. ${ }^{116}$

The Venice Commission in its Opinion of Act CLXIII of 2011 on the Prosecution Service and Act CLXIV of 2011 on the Status of the Prosecutor General, Prosecutors and other Prosecution Employees and the Prosecution Career of Hungary, adopted on 19 June 2012, noted that General Prosecutor has extremely wide powers within the prosecution system. The report from 2015 made by GRECO urged the Hungarian authorities to take additional steps to prevent abuse and increase the independence of the prosecution service by removing the possibility for the Prosecutor General to be re-elected. In addition, GRECO called for disciplinary proceedings against ordinary prosecutors to be made more transparent and for decisions to move cases from one prosecutor to another to be guided by strict legal criteria and justifications. ${ }^{117}$

Problems observed in Hungary also regarded the conflict of interests and corruption. During 2016, the Open Government Partnership Steering Committee received a letter from the Government of Hungary announcing its withdrawal from the partnerships. The Government of Hungary had been under review by Open Government Partnership as of July 2015 for concerns raised by civil society organizations, in particular regarding their space to operate in Hungary. According to the Global Competitiveness Report 2017-2018, published by the World Economic Forum, the high level of corruption was one of the most problematic factors for doing business in Hungary. ${ }^{118}$ The problems were also identified in the following areas: privacy and data protection, freedom of expression, academic freedom, freedom of religion, freedom of association, right to equal treatment, rights of persons belonging to minorities, including Roma and Jews, protection against hateful statements against such minorities, fundamental rights of migrants, asylum seekers and refugees, economic and social rights. Regarding the above mentioned issues the Council adopted the decision proclaiming that there was a clear risk in Hungary of a serious breach of the values on which the Union is founded and recommended that Hungary should take necessary actions within three months of the notification of the Council's Decision.

In its Resolution of January 16, 2020, the European Parliament noted that EU's discussion with Poland and Hungary had not yet led these countries to realign with the EU's founding values, indicating that "the situation in both Poland and Hungary has deteriorated since

${ }^{116}$ Recital (8) and (9) of the European Parliament resolution of 12 September 2018.

${ }^{117}$ Ibid. Recital (19).

${ }^{118}$ Ibid. Recitals (22) and (24). 
the triggering of Article 7(1)". ${ }^{119}$ These recent experiences with EU member states and challenges in the negotiation process with candidate countries shaped a New Methodology for Running EU Accession Negotiations that was adopted on February 5, 2020. However, the application of the methodology will depend on the rule of law progress in the member states and genuine delivery of reforms in candidate countries to ensure irreversibility of the process.

An additional instrument for protection of the rule of law in the EU is incorporated in the proposal for introduction of rule of law conditionality in the management of EU funds (Fisicaro, 2019: 696). The European Commission put forward a Proposal for a regulation on the protection of Union's budget in case of generalized deficiencies as regards the rule of law in the Member States ${ }^{120}$ in 2018, the Parliament adopted first-reading legislative resolution in April 2019, while the Council not yet adopted position.It remains to be seen how it will mitigate current challenges in the rule of law area.

As a new preventive tool, in September 2020 the European Commission for the first time prepared the Rule of Law Report that captures development of the rule of law in the EU member states. The aim of the Rule of Law Report is to identify possible problems and best practices as a basis for annual dialogue between the Commission, the Council and the European Parliament and member states on the rule of law. ${ }^{121}$

\section{COVID-19 PANDEMIC, EMERGENCY MEASURES AND RULE OF LAW SAFEGUARDS}

The particular circumstances of 2020 have brought about additional challenges for the rule of law due to COVID-19 pandemic. On 30 January 2020, World Health Organization declared COVID-19 a Public Health Emergency of International Concern, and on 11 February 2020 it was declared a global pandemic. Apart from the rapid speed of transmission of the virus, an important feature of pandemic is the lack of available and effective treatment for the disease.

In addition to the immediate health and economic impact, the COVID-19 pandemic created a variety of challenges for the public administration, legal and constitutional systems. The judiciary also needs to protect the right to life and right to health of individual judges, lawyers, prosecutors and court staff. The fact that COVID-19 mortality increases with the age may be a particular consideration since among the judiciary there is usually a higher proportion of older persons than in other professions.

As a response to the pandemic, states have taken exceptional measures to protect public health and introduced some form of state of emergency that leads to increasing executive branch powers to enable rapid procedures that derogate the normal functioning of the

\footnotetext{
${ }^{119}$ European Parliament resolution of 16 January 2020 on ongoing hearings under Article 7(1) of the TEU regarding Poland and Hungary (2020/2513(RSP).

${ }^{120}$ Commission Proposal for a Regulation of the European Parliament and of the Council on the protection of the Union's budget in case of generalised deficiencies as regards the rule of law in the Member States, $\operatorname{COM}(2018) 324$ final.

${ }^{121}$ See: https://ec.europa.eu/commission/presscorner/detail/en/qanda_20_1757 30.09.2020.
} 
democratic state. ${ }^{122}$ State of emergency does not violate the principles of the rule of law, although it does create an environment where rule of law safeguards are simultaneously more critical and difficult to uphold.

Governments across the globe have had to balance between health, economy and fundamental freedoms. Some governments introduced new surveillance techniques, including the use of drones and new data-mining technologies that use mobile phone networks to track public movements. ${ }^{123}$

Poland and Hungary have been faced with backsliding of the rule of law over the past five years and COVID-19 pandemic has made the situation even more difficult. Poland was among the first countries in the EU to enact measures limiting freedom. However, the concern was raised due to the instrument that was used and which does not exist in the Constitution. Although Constitution of Poland features potential state of emergency and provision for declaring a state of natural disaster as the only situations when fundamental rights can be limited, the Polish Government used state of epidemic as the legal grounds for limiting human rights and freedoms. The state of epidemic was introduced by the Regulation of 20 March 2020 of the Minister of Health. This decision raised discussion on legality of taken measures and on the fact that state of epidemic has no pre-fixed duration and can be prolonged by the Government. ${ }^{124}$

Hungary also imposed rigorous measures to combat the spread of COVID-19 enacting a state of emergency on 11 March 2020. Two weeks later, on March 30 the Hungarian parliament adopted law that extends government powers during pandemic and enables the Government to rule by decree without set limit and parliamentary approval. This decision raised concerns among European Parliament members, EU Commission and EU member states. ${ }^{125}$ Triggered by extended powers without any oversight, $13 \mathrm{EU}$ member states call for COVID-19 emergency measures to be temporary and in line with rule of law principles. On June 18, the Government ended the emergency rule by decree and declared a state of medical crisis until mid-December. Under the state of medical crisis, the Government is allowed to issue decrees, but cannot change laws on its own or limit human rights. ${ }^{126}$

As a response to COVID-19 a number of countries have closed courts or limited or suspended their main activities. ${ }^{127}$ Currently, only 8 percent of justice systems continue to work normally; and while 92 percent of judicial authorities are now delaying or

${ }^{122}$ See: The Impact of COVID-19 Measures on Democracy, the Rule of Law and Fundamental Rights in the EU, Policy Department for Citizens' Rights and Constitutional Affairs, European Union, PE651.343.

${ }^{123}$ Pathfinders for Peaceful, Just and Inclusive Societies, (2020) Justice in a Pandemic - Briefing One: Justice for All and the Public Health Emergency, New York, Center on International Cooperation, p. 11.

1242020 Rule of Law Report - Country Chapter on the Rule of Law Situation in Poland, SWD(2020) 320 final, p.16.

${ }^{125}$ See: https://www.politico.com/news/2020/04/01/13-countries-deeply-concerned-over-rule-oflaw-16094230.09.2020.

${ }^{126}$ See: https://www.politico.eu/article/hungary-replaces-rule-by-decree-controversial-state-of-medical-crisis/ 30.09.2020.

${ }^{127}$ International Union of Judicial Officers, Courts,https://rm.coe.int/courts-covid-19-measures-as-of-15april-2020/16809e2927 30.09.2020. 
suspending all matters except those deemed urgent, in some countries serious doubts arise as to their capacity to maintain the rule of law during the pandemic, or to prevent the arbitrary infringement of civil liberties, whether by private individuals, organizations or governmental authorities. ${ }^{128}$ This is especially challenging due to the fact that the judiciary needs to remain guardian of the rule of law and fundamental rights through review of emergency legislation.

According to Fair Trials the disruptions of court activities affected access to justice. ${ }^{129}$ The impact of measures ranges from a restricted ability to challenge executive decisions, to delays in judicial processes, challenges related to access to justice and a further increase of backlog cases in the courts due to delays of hearings.

The COVID-19 pandemic and restriction of courts operations specifically impacted certain group of cases, like cases with defendants in detention, cases where immediate protection is required for vulnerable groups (women, children), and other urgent family disputes.

In addition, it is expected that pandemic and following economic crisis will increase demand for justice as a consequence of delays and incoming new cases that have started as a result of COVID-19. ${ }^{130}$ The judiciaries across the world are already facing financing challenges and limited resources, while economic crises will only increase the existing problem. ${ }^{131}$ The scarcity of public resources will require additional strategic planning to ensure sustainable and adequate funding of judiciaries in post-COVID-19 time.

\section{COVID-19 PANDEMIC AND JUSTICE RESPONSE}

The reduced activities in courts and lockdown measures have impact on court operations. Majority of countries were looking for solutions that would limit interaction with courts and suspension of non-urgent cases was one of the applied measures. To enable functioning of the courts, countries where levels of information technology development allowed introduced modalities of online hearings and/or other use of modern technologies during proceedings, like, for instance, electronic filing. Promotion of alternative dispute resolution and court settlement was also a tool used in some of the countries.

In Hungary, the Government ordered by Decree that the functioning of Hungarian courts be suspended, apart from certain urgent cases, for an undefined period of time. ${ }^{132}$ Two weeks later, the Government introduced changes to the procedural laws, aimed at

\footnotetext{
${ }^{128}$ Impacts of COVID-19 on Justice Systems, (2020) Global Access to Justice Project, survey available at: http://globalaccesstojustice.com/impacts-of-covid-19/ 30.09.2020.

${ }^{129}$ Fair Trials (2020), COVID-19 Justice Project, https://www.fairtrials.org/covid19justice?field_tags_ tid\%5B0\%5D=1142 30.09.2020.

${ }^{130}$ The Rule of Law in the Times of Health Crisis, (2020), Advocates for International Development, Rule of Law Initiatives.

${ }^{131}$ Charging for Justice - SDG 16.3 Trend Report (2020) HILL, https://www.hiil.org/wp-content/uploads/2020/04/ HiiL-report-Charging-for-Justice-3.pdf 30.09.2020.

${ }^{132}$ Government Decree 45/2020 of 14 March 2020.
} 
facilitating the operation of the justice system during the state of danger. ${ }^{133}$ In Bulgaria, following a decision of the Judges' chamber of the Supreme Judicial Council, ${ }^{134}$ the processing of court cases was temporarily suspended for one month during the state of emergency, except for urgent cases. ${ }^{135}$ In Austria, most activity of courts was temporarily suspended from 16 March to 13 April 2020 due to the COVID-19 pandemic, with specific measures adopted to postpone procedural deadlines, which could lead to increased backlogs in the justice system. ${ }^{136}$

Although suspension or limitation of courts' operations were necessary measure at the beginning of pandemic, it was not sustainable solution and Governments and judiciary were obliged to find more suitable solutions, either through the use of information technologies, or amendments to procedural legislation and incentives for court settlements. Such an approach was taken in Italy, where Government adopted organizational measures in cooperation with the Heads of Judicial Offices and the High Council for Judiciary, allowing for remote civil and procedural hearings. ${ }^{137}$ The crisis led to an acceleration of digitalization in criminal trials, where the Prosecution service was granted the possibility to hear witnesses and examine suspects through video conference, as well as to appoint experts. ${ }^{138}$

Spain declared state of alarm on $14 \mathrm{March}^{139}$ and during the initial period of three months the activities of the courts were limited, procedural deadlines suspended, and procedural acts maintained only in urgent procedures. Concerns have been raised that these measures may have impact on the justice system as it will have to deal with the backlog generated during the state of emergency. ${ }^{140}$ Efforts are undertaken to minimize the impact of the COVID-19 pandemic on the justice system through adoption of new legislation foreseeing special procedural and organizational measures. ${ }^{141}$ The measures envisaged also include a wider use of digital technologies for procedural acts.

In Portugal, several measures were adopted related to teleworking and possibilities to hold hearings and conduct other procedures remotely. ${ }^{142}$ Deadlines in non-urgent cases

${ }^{133}$ Government Decree 74/2020 of 31 March 2020. That Decree became ineffective on 18 June 2020, in accordance with Article 53(4) of the Fundamental Law.

${ }^{134}$ Extraordinary Session, Short Protocol No. 9, 10 March 2020.

${ }^{135}$ Such as those on reviewing pre-trial detention, or undertaking victim protection measures and child protection measures.

${ }^{136}$ 1. und 2. COVID-Justizbegleitgesetz.

${ }^{137}$ Art. 83 of the Decree-law of 17 March 2020 n. 18.

1382020 Rule of Law Report - Country chapter on rule of law situation in Italy, SWD(2020) 311 final, p.5. Information received in the context of the country visit and of the consultation process for the preparation of the report, e.g. Ministry of Justice contribution (an increase of $89 \%$ in videoconferences has been registered in May 2020 with respect to May 2019).

${ }^{139}$ Royal Decree 463/2020, declaring the state of alarm as a result of the health crisis caused by COVID-19.

140 The Commission has also addressed this issue in the context of the European Semester. Recital 28, Council Recommendation on the 2020 National Reform Programme of Spain and delivering a Council opinion on the 2020 Stability Programme of Spain, p. 8 https://eur-lex.europa.eu/legal-content/EN/TXT/ PDF/?uri=CELEX:52020DC0509\&from $=E N 30.09 .2020$.

${ }^{141}$ For example, 11 to 31 August were declared working days for procedural purposes.

1422020 Rule of Law Report - Country Chapter on rule of law situation in Portugal, SWD(2020) 321 final, p. 5. 
were suspended, and non-urgent cases were adjourned. Portugal foresees a set of measures to address challenges after initial lockdown. Special focus of the measures is to address increased demand for justice and need to reduce backlog. One of the envisaged measures is a temporary regime of reduction of court fees to facilitate reaching of court agreements.

The digitalization of the justice system was used as an opportunity to overcome challenges caused by the COVID-19 pandemic. A number of initiatives are being taken ranging from allowing court users to monitor on-line the stages of proceedings to organized on-line hearings. Countries in which e-justice systems are well advanced, like Estonia and Latvia, showed a high degree of accessibility to court users and functioning of the courts continued without significant disruption during COVID-19 pandemic. ${ }^{143}$

Although the e-justice is useful tool during pandemic, there are potential challenges for use of information technologies in the justice system from an access to justice perspective, since there is significant population being digitally excluded. Plans for the future should include safeguards for all, including those who do not have access to internet.

The COVID-19 outbreak has also had an impact on the exercise of procedural rights of suspects and accused persons. Direct communication with lawyers, interpreters or with third persons (while the suspects or accused persons are deprived of liberty) is more difficult. In the Netherlands, stakeholders have raised concerns about the effective safeguarding of the right to a fair trial and quality of justice during pandemic, ${ }^{144}$ since the prosecution service has announced plans to make increased use of its power to decide itself on certain criminal cases. ${ }^{145}$ This could have an impact on the right to a fair trial, if citizens are not adequately informed. ${ }^{146}$

In France, some measures raised significant discussion. Measures relating to the functioning of the justice system included the early release of certain categories of detainees, and automatic prolongation of the length of pre-trial detention. ${ }^{147}$ Measure of automatic prolongation of the length of pre-trial detention implies putting at risk the fundamental right to liberty. ${ }^{148}$ Based on the legal action contesting the legality of prolongation, the Court of Cassation ruled that the court that would normally have decided on the prolongation should rapidly review the validity of the prolongation decision. ${ }^{149}$

In addition to legislative actions, safety measures should be adopted, such as glass

${ }^{143} 2020$ Rule of Law Report - The Rule of Law situation in the European Union, SWD(2020) 580 final, p. 11. ${ }^{144}$ See: The Netherlands Committee of Jurists for Human Rights (2020), Letter on concerns about corona measures in criminal justice.

${ }^{145}$ Such decisions by the prosecution service cannot impose a prison sentence and can be contested in court. See the Letter from the Minister for Justice and Security and the Minister for Legal Protection to the House of Representatives of 25 June 2020: 'Contours of the Approach to Address Backlogs in Criminal Justice'.

${ }^{146}$ See in that regard: National Ombudsman, Proper Provision of Information is the Basis of Access to Justice - Bottlenecks in the Provision of Information about Penalties and Dismissal Decisions.

${ }^{147}$ Art. 16, Ordinance 2020-303 of 25 March 2020.

${ }^{148}$ See also criticising a lack of clarity: Magistrates Union (2020), Automatic extension of provisional detentions: after the scandal and the mess, nonchalance!

${ }^{149}$ Judgment no. 974 of the Court of Cassation of 26 May 2020 (20-81.910). 
protections at police stations or in detention facilities, in order to enable the exercise of the right of access to lawyer or the right to an interpreter.

In Serbia, only urgent cases were tried, like pre-trial detention and cases related to the breaches of emergency rules relating to the COVID-19 pandemic. Although the Serbian Criminal Procedure Code did not envisage trial by video conference, except in specific circumstances, ${ }^{150}$ the Serbian Government adopted a decree ${ }^{151}$ by which during the state of emergency, a judge could decide that a defendant's participation can be ensured through a video link. In addition to the lack of legal basis, the measure is not in line with the European Court of Human Rights case law.

According to the jurisprudence of the European Court of Human Rights, telephone and video conference as alternative for hearings and other procedural actions, may be used if they are based in law, time-limited and demonstrably necessary and proportionate in the local circumstance and do not prevent confidential communication of a person with their lawyer. In the case Vladimir Vasilyev $v$ Russia ${ }^{152}$ it was stressed that article 6 of the European Convention of Human Rights does not guarantee the right to be heard in person at a civil court, but rather a more general right to present one's case effectively before the court and to enjoy equality of arms (para. 84).

European Court of Human Rights in case Riepan $v$ Austria ${ }^{153}$ assessed importance of publicity of trials in criminal cases. The use of video link during trial in criminal case prevents publicity and public character of criminal trial serves to maintain confidence in the courts and contributes to the achievement of a fair trial (para. 40). However, even in the criminal cases participation in the proceedings by videoconference is acceptable to the European Court of Human Rights when it is explicitly provided in the national legislation (Marcello Viola $v$ Italy, ${ }^{154}$ para. 65) and if technical conditions enable smooth transmission of the voice and images (para. 74).

It is important that use of videoconference do not prevent confidential communication with the defence counsel. The European Court of Human Rights pointed out this condition in case Marcello Viola $v$ Italy (para. 75), which was ensured through direct contact with lawyer. Since face to face meetings with lawyers were limited during pandemic the Fair Trials developed detail recommendation $\mathrm{s}^{155}$ on access to a lawyer, especially access to legal assistance for defendants in detention to ensure confidentiality. Recommendations were focused on secure and unlimited use for telephones, so that calls cannot be intercepted or recorded.

\footnotetext{
${ }^{150}$ Article 104 of the Criminal Procedure Code.

${ }^{151}$ Uredba o načinu učešća optuženog na glavnom pretresu u krivičnom postupku koji se održava za vreme vanrednog stanja proglašenog 15. marta 2020. godine, Službeni glasnik RS, broj 49/2020.

152 Application no. 28370/05, judgement of 10 January 2012.

${ }^{153}$ Application no. 3511/97, judgement of 14 February 2001.

${ }^{154}$ Application no. 45106/04, judgement 5 October 2006.

${ }^{155}$ Safeguarding the right to a fair trial during coronavirus pandemic: remote criminal justice proceedings, (2020) Fair Trials, https://www.fairtrials.org/sites/default/files/Safeguarding\%20the\%20right\%20to\%20 a $\% 20$ fair\%20trial\%20during\%20the $\% 20$ coronavirus $\% 20$ pandemic\%20remote $\% 20$ criminal $\% 20$ justice $\% 20$ proceedings.pdf, 30.09.2020.
} 
In times of COVID-19, the procedural rights of suspects and accused persons need to be respected in order to ensure fair proceedings. Limited derogations, which are provided for by the decrees, should be interpreted restrictively by the competent authorities and not be employed on a large scale.

\section{THE NEED TO STRENGTHEN THE JUSTICE DURING HEALTH EMERGENCIES}

The crisis with COVID-19 pandemic is ongoing. Although countries relaxed lockdown measures, the virus is spreading, and operation of the state institutions and judiciary is not completely returned to normal functioning. It is expected that new challenges will be during the winter when citizens will be exposed to both, regular flu and COVID-19.

It is important to ensure judicial control of decisions adopted during state of emergency to maintain public trust in institutions. To enable that the judiciary needs to be independent and separation of powers should be strengthened to prevent any abuses of executive.

In order to prepare judiciary to deal with the health emergency situation it is necessary to develop the case management system and framework and enable flexible court case triage between urgent and non-urgent case. Countries that have e-justice system should improve its functionalities to remove any unnecessary direct contacts with courts and prosecution offices. There is a need to explore if there is a need to amend legislation to ensure legal basis for use of online hearings and e-filings. However, safeguards for fair trials should be incorporated in the legislation and practice.

In addition, states and judiciary should be prepared for post-crisis period when it is expected to have increase of incoming cases on the top of created backlog. One of the solutions could be introduction of incentives for court settlement and use of alternative dispute resolutions. Pandemic is also putting pressure on alternative dispute resolutions community to find innovative solutions like e-mediation, e-arbitration and use of artificial intelligence in proceedings (Fan, 2020: 6). 


\section{REFERENCES}

Von Bogdany, A., Bogdanowicz, P., Canor, I., Taborowski, M., Schmidt, M., (2018) A potential Constitutional Moment for the European Rule of Law - The Importance of Red Lines, Common Market Law Review, Vol. 55, No. 4, p. 963-996.

Closa, C. (2016) Reinforcing EU monitoring of the rule of law. In: Closa, C., Kochenov, D. (ed.) Reinforcing Rule of Law Oversight in the European Union, Cambridge University Press, p. 15-35.

Von Danwitz, T. (2014) The Rule of Law in the Recent Jurisprudence of the ECJ', Fordham International Law JournalVol. 37, Issue 5, p. 1312-1347.

Fisicaro, M. (2019) Rule of Law Conditionality in EU Funds: The Value of Money in the Crisis of European Values, European Papers, Vol. 4, No. 3, p. 695-722.

Halmai, G. (2019) The Possibility and Desirability of Rule of Law Conditionality, Hague Journal on the Rule of Law, Vol. 11, Issue 1, p. 171-188.

Konstadinides, T. (2017) The Rule of Law in the European Union: The Internal Dimension, Hart Publishing.

Matic Boskovic, M. (2020) Role of Court of Justice of the European Union in Establishment of EU Standards on Independence of Judiciary, EU and Comparative Law Issues and Challenges Series (ECLIC), Issue 4, p. 329-351.

Müller, J.W. (2015) Should the EU Protect Democracy and the Rule of Law inside Member States? European Law Journal, Vol. 21, Issue 2, p. 141-160.

Niklewicz, K. (2017) Safeguarding the rule of law within the EU: lessons from Polish experience, European View, Vol. 16, str. 281-291.

Pech, L. Scheppele, K.L. (2017) Illiberalism Within: Rule of Law Backsliding in the EU, Cambridge Yearbook of European Legal Studies, Vol. 19, p. 3-47.

\section{INTERNET SOURCES}

Fan, K. (2020) The Impact of COVID-19 on the Administration of Justice, Kluwer Arbitration Blog, http://arbitrationblog.kluwerarbitration.com/2020/07/10/the-impact-of-covid-19on-the-administration-of-justicel

Editorial Comments, (2016) The Rule of Law in the Union, the Rule of Union Law and the Rule of Law by the Union: Three interrelated problems, Common Market Law Review,Vol 53,Issue 3, 597-606.

International Union of Judicial Officers, Courts, https://rm.coe.int/courts-covid-19measures-as-of-15-april-2020/16809e2927 
Pathfinders for Peaceful, Just and Inclusive Societies, (2020) Justice in a Pandemic Briefing One: Justice for All and the Public Health Emergency, New York, Center on International Cooperation, https://bf889554-6857-4cfe-8d55-8770007b8841.filesusr. com/ugd/6c192f_0658a70ae607408098643815ab855a65.pdf

Safeguarding the right to a fair trial during coronavirus pandemic: remote criminal justice proceedings, (2020) Fair Trials, https://www.fairtrials.org/sites/default/files/ Safeguarding\%20the\%20right\%20to\%20a\%20fair\%20trial\%20during\%20the $\% 20$ coronavirus $\% 20$ pandemic $\% 20$ remote $\% 20$ criminal $\% 20$ justice $\% 20$ proceedings.pdf

Impacts of COVID-19 on Justice Systems, (2020) Global Access to Justice Project, survey available at: http://globalaccesstojustice.com/impacts-of-covid-19/

Fair Trials (2020), COVID-19 Justice Project, https://www.fairtrials.org/covid19justice?field_ tags_tid $\% 5 \mathrm{~B} 0 \% 5 \mathrm{D}=1142$

The Rule of Law in the Times of Health Crisis, (2020), Advocates for International Development, Rule of Law Initiativeshttps://www.roleuk.org.uk/sites/default/files/files/ RULE\%20OF\%20LAW\%20IN\%20TIMES\%20OF\%20Health\%20Crises_FINAL.pdf

Charging for Justice - SDG 16.3 Trend Report (2020) HILL, https://www.hiil.org/wpcontent/uploads/2020/04/HiiL-report-Charging-for-Justice-3.pdf

https://www.politico.com/news/2020/04/01/13-countries-deeply-concerned-over-ruleof-law-160942

https://www.politico.eu/article/hungary-replaces-rule-by-decree-controversial-state-ofmedical-crisis/ 